\title{
Identification of potential vaccine target antigens by immunoproteomic analysis of a virulent and a non-virulent strain of the fish pathogen Flavobacterium psychrophilum
}

\author{
Ponnerassery S. Sudheesh ${ }^{1}$, Benjamin R. LaFrentz ${ }^{1}$, Douglas R. Call ${ }^{2}$, \\ William F. Siems ${ }^{3}$, Scott E. LaPatra ${ }^{4}$, Gregory D. Wiens ${ }^{5}$, Kenneth D. Cain ${ }^{1, *}$ \\ ${ }^{1}$ Department of Fish and Wildlife Resources and the Aquaculture Research Institute, University of Idaho, Moscow, \\ Idaho 83844-1136, USA \\ ${ }^{2}$ Department of Veterinary Microbiology and Pathology, Washington State University, Pullman, Washington 99164, USA \\ ${ }^{3}$ LBB2 Analytical Chemistry Laboratory, Washington State University, Pullman, Washington 99164, USA \\ ${ }^{4}$ Clear Springs Foods Inc., Research Division, PO Box 712, Buhl, Idaho 83316, USA \\ ${ }^{5}$ National Center for Cool and Coldwater Aquaculture, 11861 Leetown Rd, Kearneysville, West Virginia 25430, USA
}

\begin{abstract}
Flavobacterium psychrophilum is the etiological agent of bacterial coldwater disease (CWD) and rainbow trout fry syndrome (RTFS). To identify antigens associated with virulence or host immunity, we compared total and immunogenic proteins of cellular and extracellular products (ECP) between a virulent (CSF-259-93) and non-virulent (ATCC 49418) strain of F. psychrophilum. Onedimensional sodium dodecyl sulfate polyacrylamide gel electrophoresis of total cellular proteins revealed only minor differences between the strains; however, separation of ECP showed that proteins were differentially expressed. Western blot analysis using rainbow trout (Oncorhynchus mykiss) anti-CSF-259-93 sera showed greater reactivity to proteins of the virulent strain, including many $>50 \mathrm{kDa}$. Further analysis by 2-dimensional electrophoresis (2DE) identified numerous differences between the strains. Western blot analysis combined with 2DE identified several immunogenic proteins that reacted with the antisera and were shared between the 2 strains. However, at least 15 immunogenic proteins appeared to be unique to the virulent strain, while 4 such proteins were identified in the non-virulent strain; 8 proteins unique to the virulent strain and 6 shared proteins were further analyzed for identification by liquid chromatography-mass spectrometry/mass spectrometry (LC-MS/MS) analysis. Of these, 3 immunogenic proteins (heat shock proteins HSP 60 and HSP 70) and 2 other proteins (ATP synthase and thermolysin) were conclusively identified. The 2 highly immunogenic heat shock proteins were shown to share extensive homology with heat shock proteins of related bacteria. This approach for antigen identification may provide a basis for targeted vaccine development against CWD and RTFS.
\end{abstract}

KEY WORDS: Flavobacterium psychrophilum $\cdot$ Proteomics $\cdot$ Salmonid pathogen · Immunogenic antigens $\cdot$ Aquaculture vaccine

\section{INTRODUCTION}

Flavobacterium psychrophilum is a Gram-negative bacterium belonging to the Cytophaga-Flavobacterium-Bacteroides group and is the causative agent of coldwater disease (CWD) and rainbow trout fry syn- drome (RTFS). This fish pathogen can infect a broad range of hosts including salmonids (Holt et al. 1993), ayu Plecoglossus altivelis (Wakabayashi et al. 1994), and a few other fish species (Lehman et al. 1991, Iida \& Mizokami 1996, Amita et al. 2000). Fry and fingerlings are primarily affected and disease outbreaks typically 
occur at water temperatures between 3 and $15^{\circ} \mathrm{C}$ (Borg 1948, Rucker et al. 1953, Holt et al. 1989). High mortality rates and spinal deformities associated with CWD and RTFS may occur and result in large economic losses. Treatment for these diseases requires antibiotics, but success is often limited and there is concern that strains may develop resistance (Bruun et al. 2000, Michel et al. 2003). Therefore, vaccination is desired for the prevention of CWD and RTFS; however, there has been difficulty in developing a feasible and efficacious vaccine.

Immunization of rainbow trout Oncorhynchus mykiss with killed Flavobacterium psychrophilum preparations have, in general, yielded limited success for the prevention of CWD and RTFS unless the preparation is injected with adjuvant incorporation (Obach \& Laurencin 1991, LaFrentz et al. 2002, Rahman et al. 2002, Madetoja et al. 2006). This, combined with the difficulties of economical large-scale production of $F$. psychrophilum (Crump et al. 2005) has prompted studies aimed at identifying specific virulence factors and protective antigens associated with the host immune response to target for vaccine development. Several proteins from F. psychrophilum have been purified and characterized, including 2 metalloproteases (Secades et al. 2001, 2003), a membrane glycoprotein (Merle et al. 2003), and a surface layer protein (Massias et al. 2004). The role these play in virulence and in eliciting a protective immune response is not known. Other studies have utilized rainbow trout antisera to identify components recognized by the host immune system. Crump et al. (2001) identified several protein and carbohydrate antigens of F. psychrophilum and subsequently characterized and expressed a $\sim 20 \mathrm{kDa}$ hostrecognized protein antigen for use in a recombinant protein vaccine (Crump et al. 2005). LaFrentz et al. (2004) identified 3 immunogenic regions of the bacterium and demonstrated a high level of protection in rainbow trout immunized with antigens in the 70 to $100 \mathrm{kDa}$ molecular mass range. Additionally, Rahman et al. (2002) demonstrated that outer membrane components of the bacterium were highly protective. These studies indicate that protective antigens of $F$. psychrophilum exist, and a more detailed characterization of these and specific virulence factors will allow the identification of antigens to target for vaccine development.

In the present study, our goal was to compare proteins of a virulent and non-virulent strain of Flavobacterium psychrophilum to identify possible factors associated with virulence, and to incorporate immunoproteomics to identify specific proteins recognized by the host immune response. The specific objectives of this study were to compare total proteins and extracellular products (ECP) of a virulent and non-virulent strain of F. psychrophilum using single and 2-dimensional electrophoresis (2DE) and Western blotting, and to identify proteins of interest by liquid chromatography-mass spectrometry/mass spectrometry (LCMS/MS) analysis.

\section{MATERIALS AND METHODS}

Bacterial growth conditions. Bacterial strains used in this study included a virulent strain of Flavobacterium psychrophilum (CSF-259-93) and a non-virulent strain (ATCC-49418). The CSF-259-93 strain was isolated from moribund rainbow trout during an epizootic of CWD in Southern Idaho, and a subcutaneous challenge model has shown it to be highly virulent in rainbow trout (LaFrentz et al. 2002, 2003, 2004). The ATCC-49418 strain is the type strain of F. psychrophilum and intraperitoneal injection (Madsen \& Dalsgaard 2000) and subcutaneous challenge models (K. D. Cain unpubl. results) have shown it to be nonvirulent in rainbow trout. Bacteria were cultured in tryptone yeast extract salts broth (TYES, $0.4 \%$ tryptone, $0.04 \%$ yeast extract, $0.05 \%$ calcium chloride, $0.05 \%$ magnesium sulfate, $\mathrm{pH} 7.2$; Holt et al. 1993) or agar at $15^{\circ} \mathrm{C}$ for $72 \mathrm{~h}$. Single colonies from agar plates were transferred to $10 \mathrm{ml}$ TYES broth and grown at $15^{\circ} \mathrm{C}$ for $72 \mathrm{~h}$ to an optical density (OD) of 1.5 at $525 \mathrm{~nm}$. Bacteria were harvested from broth cultures by centrifugation for $15 \mathrm{~min}$ at $3000 \times g$ and washed twice in phosphate buffered saline (PBS, $\mathrm{pH}$ 7.2); the pellet was stored at $-80^{\circ} \mathrm{C}$ until needed for electrophoretic analysis.

Preparation of ECP. The ECP from the virulent and non-virulent strains of Flavobacterium psychrophilum were obtained by a cellophane overlay method (Sudheesh \& Xu 2001). This growth technique allows the bacteria to draw nutrients freely from below the cellophane sheet, and at the same time prevent mixing of the ECP proteins released by the bacteria with the proteins present in the underlying culture medium. Briefly, bacteria were grown on TYES agar plates and single colonies were transferred to TYES agar slants and cultured at $15^{\circ} \mathrm{C}$ for $72 \mathrm{~h}$. Cells were then washed with sterile $0.01 \mathrm{M}$ PBS ( $\mathrm{pH}$ 7.2). Sterile cellophane sheet overlaid TYES plates were prepared onto which $200 \mu$ of the bacterial cell suspension was spread and incubated at $15^{\circ} \mathrm{C}$ for $72 \mathrm{~h}$. Bacteria grown on the cellophane sheet overlay were washed into $2 \mathrm{ml}$ of PBS and centrifuged for $20 \mathrm{~min}$ at $15000 \times \mathrm{g}$. Following centrifugation, the supernatant containing ECP was filter sterilized with a $0.2 \mu \mathrm{m}$ membrane filter and stored at $-80^{\circ} \mathrm{C}$ until needed. The protein concentration of whole bacterial cells and ECP were determined using a Micro BCA protein assay kit (Pierce 
Biotechnology) according to the manufacturer's instructions.

Sodium dodecyl sulfate polyacrylamide gel electrophoresis (SDS-PAGE). Bacterial whole-cell lysates and ECP were analyzed by SDS-PAGE according to the method of Laemmli (1970) with some modifications. Approximately $25 \mu \mathrm{g}$ of each protein sample was diluted in sample buffer with $40 \mathrm{mM}$ dithiothreitol (DTT) and boiled for $4 \mathrm{~min}$. Samples were resolved on precast 10 to $20 \%$ polyacrylamide gradient gels (Bio-Rad) using a Mini-PROTEAN 3 electrophoresis cell (Bio-Rad). Initial gel running conditions were at $85 \mathrm{~V}$ for $15 \mathrm{~min}$ followed by $185 \mathrm{~V}$ until the dye front migrated just out of the gel. Precision Plus protein standards (Bio-Rad) were used as molecular mass standards. To determine if antigens were protein or carbohydrate in nature, Proteinase K digestion of whole bacterial and ECP protein samples was carried out in SDS-PAGE sample buffer. This simply required addition of Proteinase K (Sigma-Aldrich) at a $10 \mu \mathrm{g} \mathrm{ml} \mathrm{m}^{-1}$ final concentration followed by sample incubation at $37^{\circ} \mathrm{C}$ for $60 \mathrm{~min}$. After Proteinase $\mathrm{K}$ digestion phenylmethylsulfonyl fluoride was added to a final concentration of $1 \mathrm{mM}$ to inhibit Proteinase $\mathrm{K}$ activity.

2DE. Whole bacterial cell lysate samples for 2DE were prepared by sonicating washed cells (4 times at $50 \mathrm{~W}$ for $30 \mathrm{~s}$ on ice) in $40 \mathrm{mM}$ Tris- $\mathrm{HCl}$. Sonicated cells were treated with $150 \mathrm{U}$ of endonuclease (SigmaAldrich) and incubated for $30 \mathrm{~min}$ at room temperature. Bacterial cell lysates and ECP protein samples were extracted in sample extraction buffer, which contained $5 \mathrm{M}$ urea, $2 \mathrm{M}$ thiourea, $2 \mathrm{mM}$ tributyl phosphene (TBP), 2\% 3-[(3-cholamidopropyl)dimethylammonio]-1-propanesulfonate (CHAPS), $2 \%$ sulfobetaine $3-10,0.5 \%$ biolyte ampholyte, $10 \mathrm{mM}$ Tris and $0.001 \%$ Orange G dye. Extracted protein samples (25 $\mathrm{ug}$ total protein) were applied to $7 \mathrm{~cm}$ immobilized $\mathrm{pH}$ gradient (IPG) strips ( $\mathrm{pH} 4-7$ ) (Bio-Rad) and rehydrated overnight in a humidified chamber at room temperature. First dimension isoelectric focusing was performed on IPG strips using a Mini Protean IEF cell (Bio-Rad). The strips were focused initially for $15 \mathrm{~min}$ at $250 \mathrm{~V}, 2 \mathrm{~h}$ at $4000 \mathrm{~V}$ and then $5 \mathrm{~h}$ at $4000 \mathrm{~V}$ to achieve $20000 \mathrm{Vh}$. Focused strips were equilibrated in $5 \times$ Tris- $\mathrm{HCl}$ glycine gel buffer containing $6 \mathrm{M}$ urea, $2 \%$ SDS, $20 \%$ glycerol, $5 \mathrm{mM}$ TBP and $2.5 \%$ acrylamide monomer. Second dimension separation was carried out using precast 10 to $20 \%$ polyacrylamide gradient gels with a 2D miniprep well (Bio-Rad) on a Mini-PROTEAN 3 electrophoresis cell (Bio- Rad). Electrophoresis was performed using standard Laemmli buffer system at a constant current of $5 \mathrm{~mA}$ for $30 \mathrm{~min}$ and then at a constant current of $12 \mathrm{~mA}$ for $1.5 \mathrm{~h}$. Triplicate gel strips were prepared for each sample with the same protein concentration, and isoelectric focusing was carried out simultaneously to minimize experimental variability. Multiple gels were prepared for the same protein samples from both strains to ensure consistency of protein profile on 2DE gels. The gels were either silver-stained and scanned or stained with Sypro Ruby (Bio-Rad) and imaged under UV transillumination.

Western blot analysis. Immunogenic antigens were identified by Western blot analysis of proteins separated by SDS-PAGE and 2DE. Different pools of immune sera were obtained from juvenile rainbow trout immunized with whole-cell Flavobacterium psychrophilum (CSF-259-93) with Freund's complete adjuvant (LaFrentz et al. 2002). Antigens separated by SDS-PAGE and 2DE were transferred onto nitrocellulose membranes by electrophoresis at a constant current of $100 \mathrm{~V}$ for $1 \mathrm{~h}$ in a Mini Trans-blot electrophoretic transfer cell (Bio-Rad). The nitrocellulose membranes were blocked for $1 \mathrm{~h}$ at room temperature in PBS containing $4 \%$ non-fat dry milk. Membranes were allowed to react with the rainbow trout antiserum to $F$. psychrophilum (1:50 in PBS containing $0.05 \%$ Tween-20, $0.05 \%$ sodium azide and $4 \%$ non-fat dry milk) overnight at $15^{\circ} \mathrm{C}$. The primary fish antibody was detected by incubation of membranes for $1 \mathrm{~h}$ at room temperature with a monoclonal mouse antibody raised against trout immunoglobulin (mAb 1.14) (DeLuca et al. 1983) diluted 1:40 in PBS containing $0.05 \%$ Tween-20 and $0.05 \%$ sodium azide (PBSTAZ). Membranes with proteins transferred from 1dimensional SDS-PAGE gels were incubated for $1 \mathrm{~h}$ at room temperature with an alkaline phosphatase conjugated goat anti-mouse immunoglobulin (BioRad) diluted 1:500 in PBST-AZ. Membranes were washed 3 times in PBST-AZ between each incubation. The immunoreactive bands were visualized using 5-bromo-4-chloro-3-indolylphosphate toluidine salt and 4-nitro blue tetrazolium chloride (Bio-Rad). The Western blot analysis of membranes with proteins transferred from 2DE gels was visualized by incubating an anti-mouse IRDye-800 (Rockland Immunochemicals) conjugated rabbit antiserum $(1: 10000)$ with the secondary, antibody bound membranes for $1 \mathrm{~h}$ in the dark. Blocking and antibody binding reactions of IRDye conjugated membranes were done in blocking buffer for near infrared fluorescent Western blotting (Rockland) according to the manufacturer's instructions. The membranes were scanned with an Odyssey infrared scanner (Li-COR Biosciences).

LC-MS/MS analysis. Individual protein spots were cut out from Sypro Ruby stained gels using sterile scalpels and in-gel tryptic digestion was carried out with slight modifications of previous protocols 
(Shevchenko et al. 1996, Jensen et al. 1999, Rowley et al. 2000). Briefly, each 2DE gel piece was washed in $50 \mu \mathrm{l}$ of $100 \mathrm{mM}$ ammonium bicarbonate and dehydrated in $100 \%$ acetonitrile $(\mathrm{ACN})$. The gels were rehydrated with $50 \mu \mathrm{l}$ of $10 \mathrm{mM}$ DTT in $100 \mathrm{mM}$ ammonium bicarbonate. Cysteines were reduced by heating at $56^{\circ} \mathrm{C}$ for 30 min and alkylated by incubating the samples with $55 \mathrm{mM}$ iodoacetamide in $100 \mathrm{mM}$ ammonium bicarbonate. Samples were washed in $100 \mathrm{mM}$ ammonium bicarbonate, treated with ACN once again and dried in a Speedvac (Thermo Savant). The samples were rehydrated in digestion buffer containing $50 \mathrm{mM}$ ammonium bicarbonate and sequencing grade

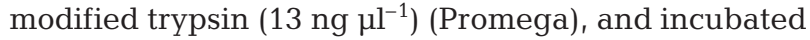
overnight at $37^{\circ} \mathrm{C}$. The following day, samples were extracted with $60 \%$ ACN/1 \% trifluro-acetic acid (TFA) for $15 \mathrm{~min}$ and sonicated in an ultrasonic water bath (Branson Ultrasonics) for $10 \mathrm{~min}$. The extraction and sonication was repeated with $3 \%$ TFA. LC-MS/MS of the peptide digests were performed on a Thermo Finnigan LTQ Fourier Transform Mass Spectrophotometer (Thermo Electron Corporation) at the proteomics laboratories of Washington State University (Pullman) and Michigan State University (East Lansing). For LC-MS/MS analysis the extracted peptides were injected onto a peptide trap (Agilent Zorbax 300 SB-C18 $5 \times 0.3 \mathrm{~mm}$ ). The bound peptides were then eluted onto a $15 \mathrm{~cm} \times 75 \mathrm{um}$ column (New Objectives Picofrit) packed with Microm Magic C18 AQ packing material and eluted over 30 min with a gradient of $5 \%$ to $90 \% \mathrm{~B}$, with constant $10 \% \mathrm{C}$ in 24 min using a Michrom Paradigm LC (Buffer A $=100 \%$ water, Buffer $\mathrm{B}=100 \%$ acetonitrile, Buffer $\mathrm{C}=1 \%$ formic acid) into a Thermo Electron LTQ-FTICR mass spectrometer with a flow rate of $250 \mathrm{nl} \mathrm{min}{ }^{-1}$. Survey scans were taken at $100000 \times$ resolution and the top 5 ions in each survey scan were then subjected to automatic low energy, collision-induced dissociation (CID) in the LTQ.

Sequencing and database searches. Sequence homology analysis was performed by using the BLAST and PSI-BLAST algorithms (www.ncbi.nlm.nih.gov/). Pair-wise sequence alignments and multiple sequence alignments were carried out using ClustalW (www.ebi. ac.uk/clustalw/). LC-MS/MS peptide sequence data were analyzed using Mascot search (www.matrixscience.com/) against Swiss-Prot (http://ca.expasy.org/ sprot/), UniProt (www.ebi.uniprot.org/index.shtml), NCBI-GenBank (www.ncbi.nlm.nih.gov/Genbank/ index.html) and other public databases. Significant hits were assigned probability-based Mowse scores based on ion score, which is $-10 \times \log (p)$, where $p$ is the probability that the observed match is a random event. Individual ion scores $>24(p<0.05)$ indicate identity or extensive homology. Protein scores were derived from ion scores as a non-probabilistic basis for ranking protein hits. The MS/MS spectra were converted to peak lists using BioWorks Browser Version 3.2 and searched against an appropriate database using the Mascot searching algorithm. Identifications were considered positive if 2 peptides per protein were identified with a significant Mascot score $(p<0.05)$. Estimation of theoretical molecular weights and isoelectric points were performed using the Compute $\mathrm{pI} / \mathrm{Mw}$ algorithm (http://ca.expasy.org/) (Bjellqvist et al. 1993). The peptide sequences were also compared to a Flavobacterium psychrophilum (CSF-259-93) draft genome sequence data (G. D. Wiens et al. unpubl. data).

\section{RESULTS}

\section{SDS-PAGE}

The electrophoretic patterns of whole-cell lysates from the CSF-259-93 and ATCC-49418 strains of Flavobacterium psychrophilum are similar and only minor variations in band intensity were observed (Fig. 1A). For example, the intensity of 2 bands with approximate molecular masses of 18 and $19 \mathrm{kDa}$ were greater in the ATCC-49418 strain when compared visually with the CSF-259-93 strain.

SDS-PAGE analysis of the ECP did show differences between the 2 strains of Flavobacterium psychrophilum (Fig. 1B). At least 5 bands were identified as being unique to the ECPs of the CSF-259-93 strain, and at least 3 bands were present only in the ATCC-49418 strain. In addition to the presence and absence of the aforementioned bands, it should be noted that slight differences in the staining intensity of several shared bands were observed (Fig. 1B).

\section{DE}

2DE analysis of the ECP of the CSF-259-93 and ATCC-49418 strains revealed differences in secreted proteins of these strains (Fig. 2). Using this method of separation, at least 5 proteins were identified as unique to the CSF-259-93 strain and at least 2 proteins were unique to the ATCC-49418 strain.

Whole-cell lysates extracted from the CSF-259-93 and ATCC-49418 strains of Flavobacterium psychrophilum were also separated and further analyzed by 2DE. This provided increased resolution over single dimension SDS-PAGE and demonstrated that differences exist between the strains (Fig. 3). In addition to numerous shared proteins, at least 8 proteins were identified as being unique to the CSF-259-93 strain (Fig. 3, circled spots), and at least 1 protein was unique to the ATCC-49418 strain. 

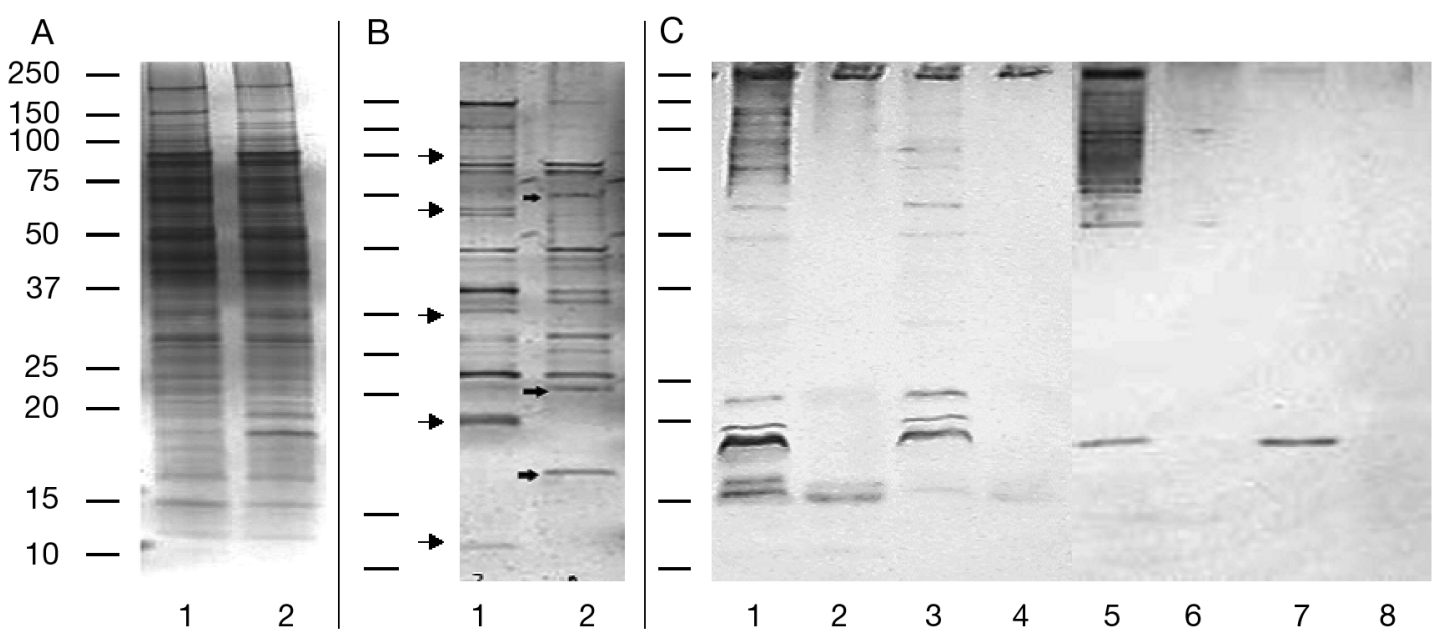

Fig. 1. Flavobacterium psychrophilum. (A) SDS-PAGE of whole cells: Lane 1, Strain CSF-259-93; Lane 2, Strain ATCC-49418. (B) SDS-PAGE of extracellular products (ECP) of F. psychrophilum: Lane 1, CSF-259-93; Lane 2, ATCC-49418; arrows indicate unique protein bands. (C) Western blot analysis of whole cells and ECP probed with trout anti-F. psychrophilum antiserum; Lane 1, CSF-259-93 whole cells; Lane 2, Proteinase K-digested CSF-259-93 whole cells; Lane 3, ATCC-49418 whole cells; Lane 4 , Proteinase K-digested ATCC-49418 whole cells; Lane 5, ECP of CSF-259-93; Lane 6, Proteinase K-digested ECP of CSF-259-93; Lane 7, ECP of ATCC-49418; Lane 8, Proteinase K-digested ECP of ATCC-49418. Molecular mass markers (kDa) relate to (A), (B) and (C)

\section{Western blot analysis: SDS-PAGE}

Western blot analysis, using rainbow trout anti-CSF259-93 serum, was utilized to probe whole-cell lysates and ECP of both the CSF-259-93 and ATCC-49418 strains. Antibodies reacted with numerous bands of the CSF-259-93 strain with high molecular masses of $>50 \mathrm{kDa}$, as well as several low molecular mass bands ranging from 15 to $21 \mathrm{kDa}$ (Fig. 1C). However, following Proteinase $\mathrm{K}$ digestion, only the 15 and $16 \mathrm{kDa}$ bands were visualized (Fig. 1C). When used to probe the ATCC-49418 whole-cell lysate, antibodies primarily reacted with 3 low molecular mass bands ranging from 18 to $21 \mathrm{kDa}$ and a small number of high molecular mass bands. Upon Proteinase $\mathrm{K}$ digestion, no bands were visualized (Fig. 1C).

Western blot analysis of the ECP of both strains revealed similar differences in immunoreactivity (Fig. 1C). The antiserum reacted with multiple high molecular mass proteins $>50 \mathrm{kDa}$ and an $18 \mathrm{kDa}$ band in the CSF-259-93 strain, but antibodies only reacted with the $18 \mathrm{kDa}$ band in the ATCC-49418 strain. Following Proteinase K digestion, no bands were visualized for either strain. It was particularly noted that very few bands in the 25 to $60 \mathrm{kDa}$ region of all whole-cell and ECP samples reacted with the antiserum com-
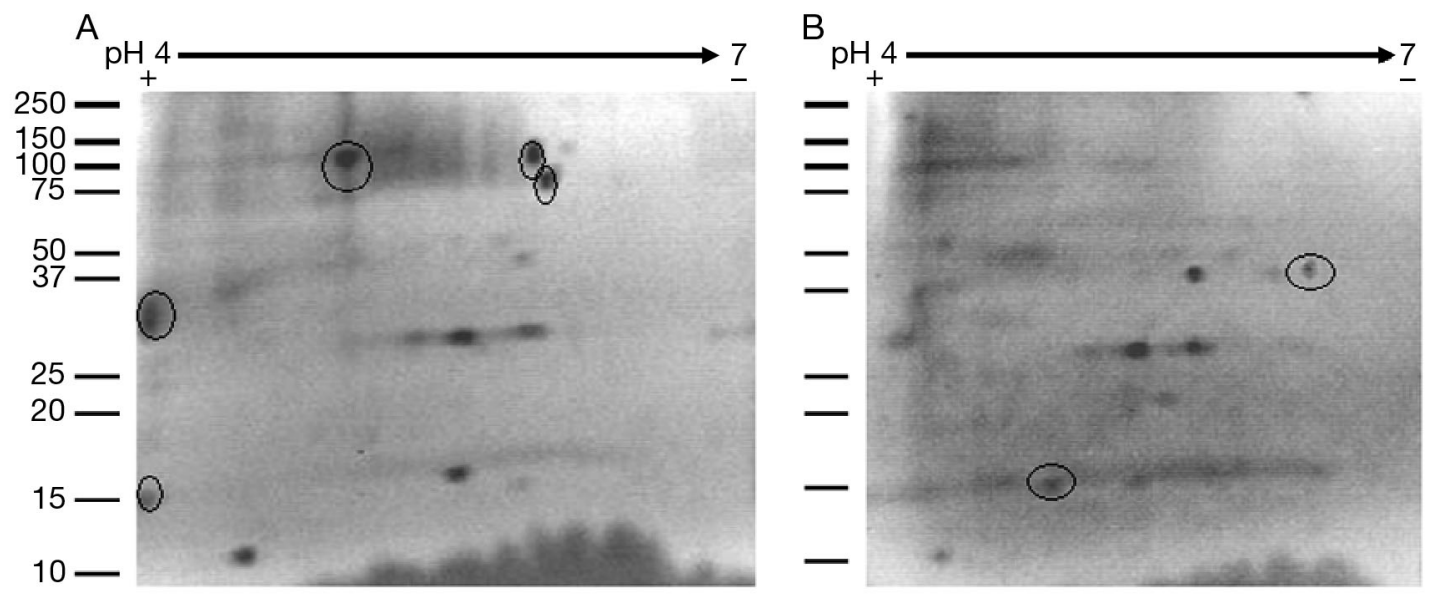

Fig. 2. Flavobacterium psychrophilum. 2DE analysis of ECP proteins (A) Strain CSF-259-93; (B) Strain ATCC-49418. Spots unique to each strain are circled. Molecular mass markers (kDa) relate to both (A) and (B) 


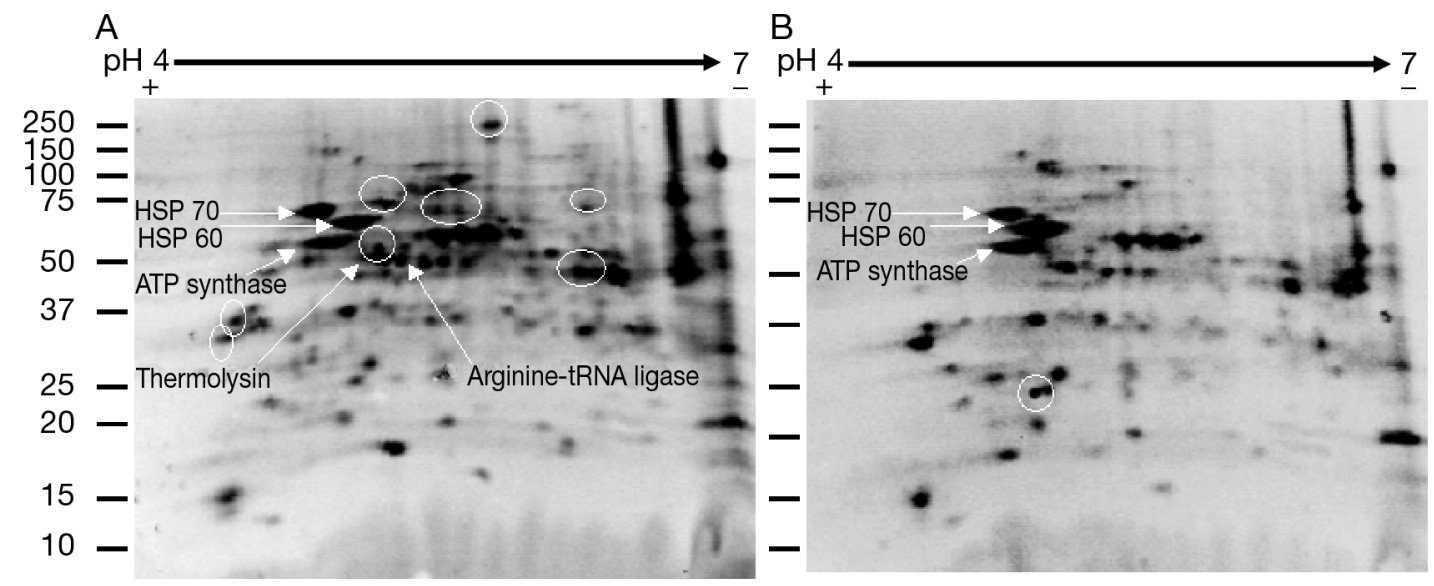

Fig. 3. Flavobacterium psychrophilum. 2DE analysis of whole-cell proteins. (A) Strain CSF 259-93; (B) Strain ATCC-49418. Spots unique to each strain are circled. Molecular mass markers $(\mathrm{kDa})$ relate to both $(\mathrm{A})$ and $(\mathrm{B})$

pared to other higher and lower molecular weight bands, and this was observed consistently in several repeated Western blot preparations.

\section{Western blot analysis: 2DE}

To allow further analysis and possible identification of protein antigens, Western blot analysis was also performed on whole-cell lysates separated by 2DE from the CSF-259-93 and ATCC-49418 strains of Flavobacterium psychrophilum using the anti-CSF-259-93 serum (Fig. 4). As observed with single dimension SDS-PAGE, antibodies reacted with more antigens in the CSF-259-93 strain than in the ATCC-49418 strain. Approximately 15 spots unique to the CSF-259-93 strain were shown to react with the trout antiserum, while 4 spots unique to the ATCC-49418 strain were recognized. Control antiserum showed no binding by Western blotting (data not shown).

\section{LC-MS/MS analysis}

The 8 proteins that appeared unique to the CSF-25993 strain and 6 proteins shared between the 2 strains and isolated from the whole cell fractions were selected and analyzed by LC-MS/MS. This analysis followed by a Mascot search using peptide fragment sequences against public databases identified 5 proteins (Table 1). Two shared proteins of approximate molecular weights of 60 and $70 \mathrm{kDa}$ were identified as heat shock proteins HSP 60 and HSP 70, respectively. The short peptide sequences obtained from LCMS/MS analysis were further searched against a preliminary draft genome database of Flavobacterium

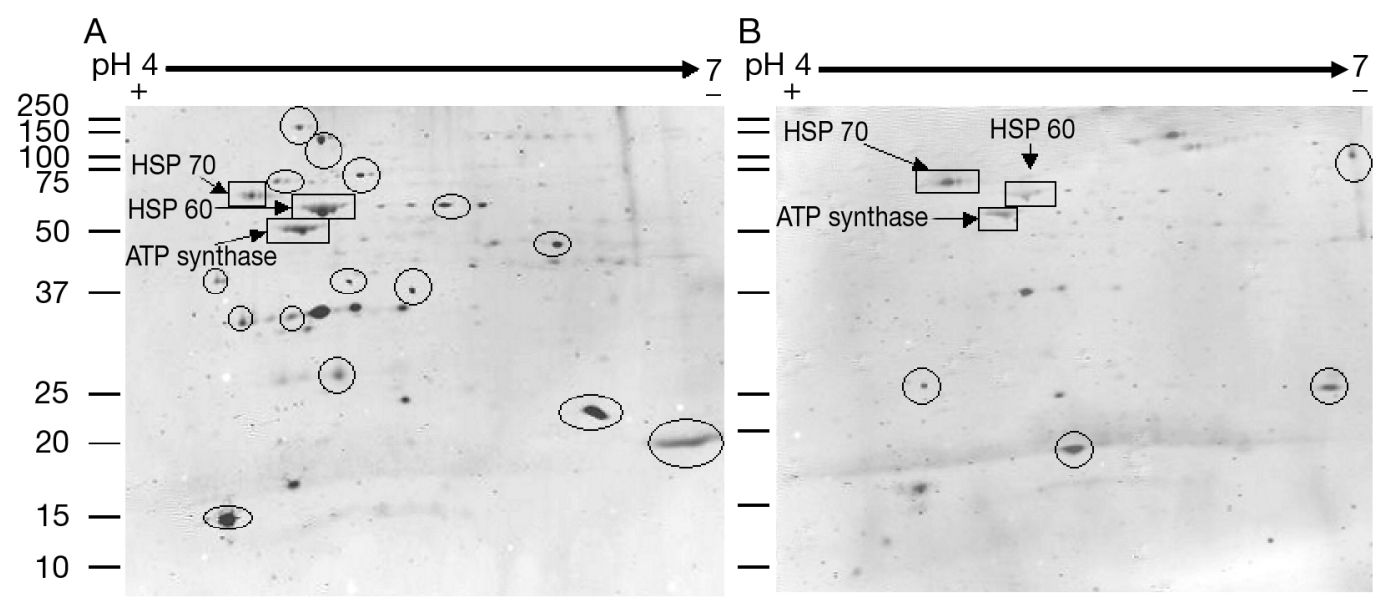

Fig. 4. Flavobacterium psychrophilum. Western blot analysis of whole-cell proteins separated by 2DE gels. (A) Strain CSF-259-93; (B) Strain ATCC-49418. Antigens unique to each strain are circled, highly immunogenic common antigens are enclosed in rectangles. Molecular mass markers $(\mathrm{kDa})$ relate to both $(\mathrm{A})$ and $(\mathrm{B})$ 
Table 1. Flavobacterium psychrophilum. LC-MS/MS analysis of selected proteins. Seq. cov.: sequence coverage; pI: isoelectric point

\begin{tabular}{|c|c|c|c|c|c|c|}
\hline $\begin{array}{l}\text { Protein } \\
\text { spot no. }\end{array}$ & $\begin{array}{l}\text { Description (GenBank } \\
\text { Accession No.) }\end{array}$ & Queries matched & $\begin{array}{l}\text { Seq. cov. } \\
(\%)\end{array}$ & $\begin{array}{l}\text { Nominal } \\
\text { mass (Da) }\end{array}$ & $\begin{array}{c}\text { Calculated } \\
\text { pI }\end{array}$ & Score \\
\hline $1^{\mathrm{a}}$ & $\begin{array}{l}60 \mathrm{kDa} \text { chaperonin } \\
\text { (F.psychrophilum) } \\
\text { (AAX56915) }\end{array}$ & $\begin{array}{l}\text { NIKFDIEAR.D } \\
\text { GVDALANAVKVTLGPK.G } \\
\text { AAVEEGIVAGGGVALLR.A } \\
\text { TIVENAGLEGSVVVAK.V } \\
\text { GFTLENTTIEMLGTAK.R + } \\
\text { Oxidation }\end{array}$ & 15.5 & 57107 & 4.99 & 213 \\
\hline $2^{\mathrm{a}}$ & $\begin{array}{l}70 \mathrm{kDa} \text { heat shock protein } \\
\text { (F.psychrophilum) } \\
\text { (AAX56916) }\end{array}$ & $\begin{array}{l}\text { IADEVEKFFGK.K } \\
\text { AKFEQLSDTLVK.R } \\
\text { IEASSGLTSEEIER.M } \\
\text { LYTAQELSAMTLQK.M + Oxidation } \\
\text { IINEPTAAALAYGLDKK.G }\end{array}$ & 13 & 67377 & 4.83 & 173 \\
\hline $3^{b}$ & $\begin{array}{l}\text { Arginine-tRNA ligase } \\
\text { (Flavobacterium johnsoniae) } \\
\text { UW101 (ZP_01245348) }\end{array}$ & $\begin{array}{l}\text { MSLQEILNPSIK.T + Oxidation } \\
\text { (M) TQIINDRGIHICK.S }\end{array}$ & 4.8 & 67899 & 5.63 & 36 \\
\hline $4^{\mathrm{a}}$ & $\begin{array}{l}\text { F0F1-type ATP synthase, } \\
\text { alpha subunit (Cytophaga } \\
\text { hutchinsonii) (ZP_00309791) }\end{array}$ & $\begin{array}{l}\text { QPVTEPLQTGIK } \\
\text { DTGRPALVVYDDLSK } \\
\text { VGGNAQIK }\end{array}$ & 9 & 56812 & 6.16 & 208 \\
\hline $5^{c}$ & $\begin{array}{l}\text { Thermolysin (Bacillus } \\
\text { thermoproteolyticus) } \\
\text { (720316A) }\end{array}$ & $\begin{array}{l}\text { LSYDGNNAAIR } \\
\text { ALTQYLTPTSNFSQLR } \\
\text { AAAVQSATDLYGSTSZZVASVK } \\
\text { QAFDAVGVK }\end{array}$ & 30 & 34313 & 5.03 & 476 \\
\hline
\end{tabular}

psychrophilum (CSF-259-93) and matched with open reading frames ORF RFPS02405 and ORF RFPS00215 in the database, corresponding to groEL (HSP 60) and dnaK (HSP 70) genes, respectively.

Three other proteins were identified by LC-MS/MS; an ATP synthase-alpha subunit homologue (shared by both strains), a thermolysin (unique to CSF-259-93), and an arginine-tRNA ligase that also appears shared by both strains (Table 1). The peptide fragment sequences of these proteins obtained by LC-MS/MS were also searched against the draft genome sequence of Flavobacterium psychrophilum. The ATP synthasealpha subunit homologue and the arginine-tRNA ligase were confirmed to be ORF RFPS01834 and RFPS01165, respectively, but the thermolysin protein could not be matched with any ORF.

Nucleotide and translated protein sequences of both groEL and $d n a K$ genes were compared with reported sequences of related bacteria, Flavobacterium ferrugineum, F. hydatis, Cytophaga hutchinsonii and other non-related bacteria using the ClustalW program, and were found to share many conserved regions and per-

Table 2. Sequence homology of groEL and dnaK genes of Flavobacterium psychrophilum to those of other bacteria. Aa: amino acid; \% sim: percent similarity; na: not available

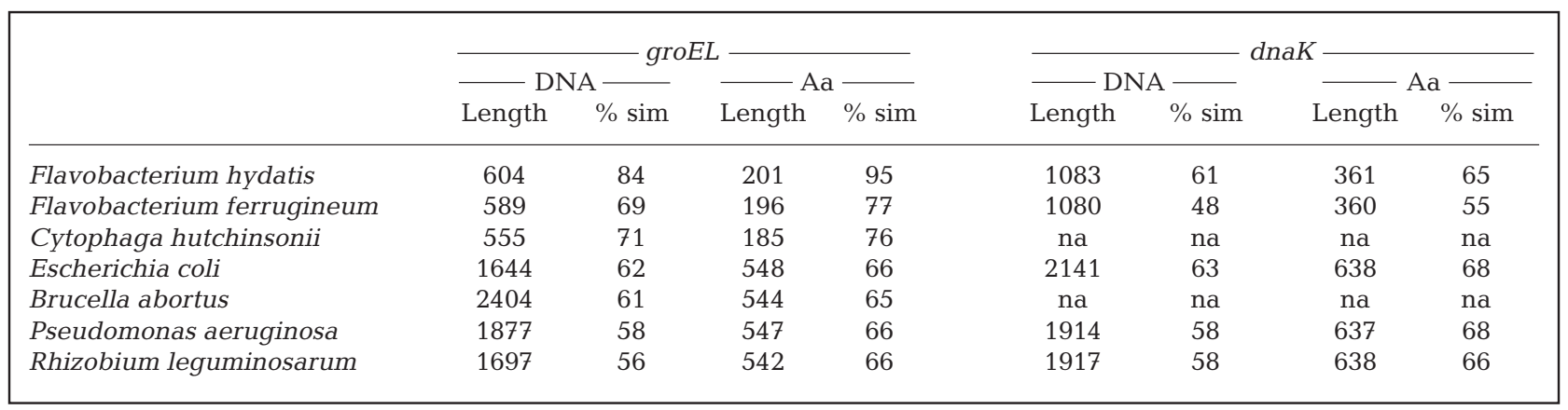


cent similarities ranging from 48 to $95 \%$ (Table 2). The complete DNA sequence of the groEL gene and the partial sequence of the dnaK gene of $F$. psychrophilum have been deposited in GenBank under Accession Nos. AY955285 and AY955286, respectively.

\section{DISCUSSION}

Development of an efficacious vaccine for CWD has been hindered by our lack of understanding of the pathogen and the host immune response. Research efforts in the past have focused on using vaccine preparations composed of either killed whole cells or groups of antigens of unknown identity. This study utilized standard SDS-PAGE and proteomics (2DE) to identify protein antigens possibly associated with virulence or host immunity. The application of 2DE to the study of fish pathogens is limited. Tan et al. (2002) and Srinivasa et al. (2004) used 2DE to identify virulence factors in the ECP of Edwardsiella tarda. In other studies, 2DE was used to differentiate expression of outer membrane proteins of Aeromonas salmonicida in response to low iron and in vivo growth conditions (Ebanks et al. 2004) and to identify the major outer membrane proteins of this pathogen (Ebanks et al. 2005). In addition, 2DE techniques have been combined with Western blotting and gene mining to identify antigens from Helicobacter pylori (Nilsson et al. 2000), Staphylococcus aureus (Vytvytska et al. 2002), Bacillus anthracis (Ariel et al. 2003), Haemophilus influenzae (Langen et al. 2000), as well as Flavobacterium psychrophilum (Crump et al. 2005).

The results of this study show that following initial separation of whole cell proteins and ECPs of Flavobacterium psychrophilum by single dimension SDS-PAGE, potential differences exist between a virulent (CSF-259-93) and non-virulent (ATCC 49418) strain (Fig. 1A,B). Further characterization by Western blotting revealed several unique immunogenic bands in whole cell and ECP products of the CSF-259-93 strain compared to the ATCC 49418 strain. Western blot analysis of total cellular proteins using anti-CSF259-93 sera clearly showed that many proteins of $>50$ $\mathrm{kDa}$ molecular mass and a few low molecular mass proteins of 15 to $21 \mathrm{kDa}$ were highly immunogenic in the virulent strain (Fig. 1C, Lane 1). This is supported by earlier studies investigating the immunogenic nature of this bacterium (LaFrentz et al. 2004).

In both strains, 3 bands in the 18 to $21 \mathrm{kDa}$ region were equally reactive. Previously, it was shown that rainbow trout convalescent antiserum recognized a predominant $20 \mathrm{kDa}$ protein (Crump et al. 2001) and rabbit antiserum recognized an $18 \mathrm{kDa}$ surface layer protein (Massias et al. 2004). Hence, the 18 to $21 \mathrm{kDa}$ bands observed in our study are likely to have been the same proteins reported in these earlier studies. The $15 \mathrm{kDa}$ and $16 \mathrm{kDa}$ antigens of the CSF-259-93 strain identified by Western blotting of the whole-cell preparation may be a carbohydrate (possibly associated with lipopolysaccharide), since it was not susceptible to Proteinase $\mathrm{K}$ digestion. This agrees with findings of Crump et al. (2001) and LaFrentz et al. (2004), who partially characterized lipopolysaccharide (LPS) components. Although identification of these components is important, the possibility that more than 1 antigen occurs at a particular band position (molecular mass) makes interpretation of SDS-PAGE data difficult. This is apparent in Fig. 1B, where a band at $18 \mathrm{kDa}$ was only observed in the ECP proteins of the ATCC 49418 strain, whereas when analyzed by Western blotting (Fig. 1C) a band at the $18 \mathrm{kDa}$ position reacted with the antiserum in both strains.

LaFrentz et al. (2004) demonstrated that whole-cell antigens of Flavobacterium psychrophilum CSF-25993 in the approximate molecular mass range of 70 to $100 \mathrm{kDa}$ were immunogenic and conferred near complete protection following immunization. Based on this, proteins of higher molecular mass were our primary focus. Although ECPs from both strains were analyzed by 2DE and differences were found (Fig. 2), protein spots were not further characterized. Since total cellular proteins were analyzed in the LaFrentz et al. (2004) study, we decided to give these priority for further identification. When total cellular proteins were separated by $2 \mathrm{DE}$, at least 8 protein spots appeared to be unique to the virulent strain. Based on this analysis and our desire to characterize proteins primarily in the higher molecular mass ranges, the 8 cell-associated proteins unique to CSF-259-93, and 6 shared proteins (some of which were immunogenic) were analyzed by LC-MS/MS. Among them, 5 proteins were conclusively identified ( 3 immunogenic and shared between strains, 1 shared, and 1 unique to CSF-259-93) (Table 1). Of these, the identity of the 3 immunogenic proteins (nos. 1, 2, and 4 in Table 1) was further confirmed by comparison with a preliminary draft genome of F. psychrophilum. PCR amplification identified the genes encoding HSP 60 and HSP 70 as groEL and dnaK, respectively, and nucleotide comparisons showed extensive homology with HSPs of related and unrelated bacteria (Table 2).

The 2 highly immunogenic proteins identified as heat shock proteins HSP 60 and HSP 70 were of particular interest. They were expressed in both the virulent and non-virulent strains of Flavobacterium psychrophilum, and HSPs are known to be important targets of the host immune response in other pathogens (Wilhelm et al. 2005). Heat shock proteins are considered molecular chaperones expressed by prokaryotes and 
eukaryotes that bind polypeptide chains, prevent aggregation, and support protein folding (Bukau \& Horwich 1998). Their expression in most organisms is increased during stress, and bacterial HSPs are upregulated during the course of most bacterial infections. Bacterial HSPs have been recognized as immunodominant antigens that swamp the host immune system with epitopes (Buchmeier \& Heffron 1990, Lee \& Horwitz 1995, Qoronfleh et al. 1998, Zügel \& Kaufmann 1999).

The protein spots identified here as HSP 60 and HSP 70 were highly reactive against trout antiserum by Western blot (Fig. 4) indicating that these are indeed immunodominant antigens of the bacteria. Several studies have shown that anti-HSP responses are protective against many bacterial pathogens (Kaufmann et al. 1991, Blander \& Horwitz 1993, Noll et al. 1994, Suzue \& Young 1996). In addition, studies have shown that in some bacteria HSPs are located in the periplasm, on the bacterial surface and in some cases secreted into the surrounding medium (Gillis et al. 1985, Scorpio et al. 1994, Garduño et al. 1998, Hoffman \& Garduño 1999, Hennequin et al. 2001). They have been implicated as bacterial virulence factors playing a significant role in mediating attachment. There are also reports suggesting that bacterial HSPs are ubiquitous host-evasion factors countering oxidative killing mechanisms of the host (Kaufmann 1989). In addition, they may provide immuno-stimulatory activity (Barrios et al. 1992, Noll et al. 1994) and act as B cell mitogens (Aosai et al. 2002, Rico et al. 2002). They have novel functions associated with activation of professional antigen-presenting cells (Kol et al. 2000, Bulut et al. 2002) and stimulation of cytokine (Asea et al. 2000) and chemokine production (Wang et al. 2001). The combined roles of HSPs as antigens and immunomodulators have led to the suggestion that they might provide an important link between innate and acquired immune responses (Srivastava et al. 1998). Recently, it was shown that fish immunized using recombinant HSP 60 and HSP 70 from another salmonid pathogen, Piscirickettsia salmonis, elicited a humoral immune response when intraperitoneally injected in Atlantic salmon Salmo salar, and protection was also conferred to fish challenged with $P$. salmonis (Wilhelm et al. 2005). These findings are interesting and suggest that the HSP proteins identified in this study may provide possible vaccine targets.

This study has demonstrated the usefulness of proteomics in the discovery of vaccine candidates of Flavobacterium psychrophilum. The approach presented here is unique in that targets are selected based on their presence within the pathogen, and their potential relationship to virulence or host immunity. Although further characterization of a number of these proteins is needed, the identification and isolation of genes encoding HSP 60 and HSP 70 of F. psychrophilum is significant and provides targets for vaccine efficacy studies.

Acknowledgements. We acknowledge the Washington State University Proteomics Laboratory, and B. S. Phinney and J. Kuchar of Michigan State University for LC/MS-MS analysis of our samples. This research was funded by the Idaho and Washington Aquaculture Initiative USDA-CSREES (Award No. 99-38500-7507) and the Agricultural Animal Health Program, College of Veterinary Medicine, Pullman, Washington.

\section{LITERATURE CITED}

Amita K, Hoshino M, Honma T, Wakabayashi H (2000) An investigation on the distribution of Flavobacterium psychrophilum in the Umikawa River. Fish Pathol 35:193-197

Aosai F, Chen M, Kang HK, Mun HS and 6 others (2002) Toxoplasma gondii-derived heat shock protein HSP70 functions as a B cell mitogen. Cell Stress Chaperones 7:357-364

Ariel N, Zvi A, Makarova KS, Chitlaru T and 5 others (2003) Genome-based bioinformatic selection of chromosomal Bacillus anthracis putative vaccine candidates coupled with proteomic identification of surface-associated antigens. Infect Immun 71:4563-4579

Asea A, Kraefi SK, Kurt-Jones EA, Stevenson MA, Chien LB, Finberg RW, Koo GC, Calderwood SK (2000) HSP70 stimulates cytokine production through a CD14-dependent pathway, demonstrating its dual role as a chaperone and cytokine. Nat Med 6:435-442

Barrios C, Lussow AR, Van Embden J, Van der Zee R and 5 others (1992) Mycobacterial heat-shock proteins as carrier molecules. II. The use of the $70-\mathrm{kDa}$ mycobacterial heat shock protein as carrier molecules for conjugated vaccines can circumvent the need for adjuvants and Bacillus Calmette Guérin priming. Eur J Immunol 22:1365-1372

Bjellqvist B, Hughes, GJ, Pasquali C, Paquet N, Ravier F, Sanchez JC, Frutiger S, Hochstrasser DF (1993) The focusing positions of polypeptides in immobilized $\mathrm{pH}$ gradients can be predicted from their amino acid sequences. Electrophoresis 14:1023-1031

Blander SJ, Horwitz MA (1993) Major cytoplasmic membrane protein of Legionella pneumophila, a genus common antigen and member of the hsp 60 family of heat shock proteins, induces protective immunity in a guinea pig model of Legionnaires' disease. J Clin Investig 91:717-723

Borg AF (1948) Studies on myxobacteria associated with diseases in salmonid fishes. $\mathrm{PhD}$ dissertation, University of Washington, Seattle

Bruun MS, Schmidt AS, Madsen L, Dalsgaard I (2000) Antimicrobial resistance patterns in Danish isolates of Flavobacterium psychrophilum. Aquaculture 187:201-212

Buchmeier NA, Heffron F (1990) Induction of Salmonella stress proteins upon infection of macrophages. Science 248:730-732

Bukau B, Horwich AL (1998) The Hsp70 and Hsp60 chaperone machines. Cell 92:351-366

Bulut Y, Faure E, Thomas L, Karahashi H and 5 others (2002) Chlamydial heat shock protein 60 activates macrophages and endothelial cells through toll-like receptor 4 and MD2 in a MyD88-dependent pathway. J Immunol 168: $1435-1440$

Crump EM, Perry MB, Clouthier SC, Kay WW (2001) Antigenic characterization of the fish pathogen Flavobac- 
terium psychrophilum. Appl Environ Microbiol 67: $750-759$

Crump EM, Burian J, Allen PD, Kay WW (2005) Identification and expression of a host-recognized antigen, FspA, from Flavobacterium psychrophilum. Microbiology (Reading) 151:3127-3135

DeLuca D, Wilson M, Warr GW (1983) Lymphocyte heterogeneity in the trout, Salmo gairdneri, defined with monoclonal antibodies to IgM. Eur J Immunol 13:546-551

Ebanks RO, Dacanay A, Goguen M, Pinto DM, Ross NW (2004) Differential proteomic analysis of Aeromonas salmonicida outer membrane proteins in response to low iron and in vivo growth conditions. Proteomics 4:1074-1085

Ebanks RO, Goguen M, McKinnon S, Pinto DM, Ross NW (2005) Identification of the major outer membrane proteins of Aeromonas salmonicida. Dis Aquat Org 68:29-38

Garduño RA, Garduño E, Hoffman PS (1998) Surface-associated Hsp60 chaperonin of Legionella pneumophila mediates invasion in a HeLa cell model. Infect Immun 66:4602-4610

Gillis TP, Miller RA, Young DB, Khanolkar SR, Buchanan TM (1985) Immunochemical characterization of a protein associated with Mycobacterium leprae cell wall. Infect Immun 49:371-377

Hennequin C, Porcheray F, Waligora-Dupriet AJ, Collignon A, Barc MC, Bourlioux P, Karjalainen T (2001) GroEL (Hsp60) of Clostridium difficile is involved in cell adherence. Microbiology (Reading) 147:87-96

Hoffman PS, Garduño RA (1999) Surface-associated heat shock proteins of Legionella pneumophila and Helicobacter pylori: roles in pathogenesis and immunity. Infect Dis Obstet Gynecol 7:58-63

Holt RA, Amandi A, Rohovec JS, Fryer JL (1989) Relation of water temperature to bacterial cold-water disease in coho salmon, chinook salmon, and rainbow trout. J Aquat Anim Health 1:94-101

Holt RA, Rohovec JS, Fryer JL (1993) Bacterial coldwater disease. In: Inglis V, Roberts RJ, Bromage NR (eds) Bacterial diseases of fish. Blackwell Scientific Publications, Oxford, p 3-23

Iida Y, Mizokami A (1996) Outbreaks of coldwater disease in wild ayu and chub. Fish Pathol 31:157-164

Jensen ON, Wilm M, Shevchenko A, Mann M (1999) Peptide sequencing of 2-DE gel-isolated proteins by nanoelectrospray tandem mass spectrometry. Methods Mol Biol 112: 571-588

Kaufmann SH (1989) Stress proteins: virulence factors of intracellular disease agents? Immun Infekt 17:124-128

Kaufmann SH, Schoel B, van Embden JD, Koga T, WandWurttenberger A, Munk ME, Steinhoff U (1991) Heatshock protein 60: implications for pathogenesis of and protection against bacterial infections. Immunol Rev 121: 67-90

Kol A, Lichtman AH, Finberg RW, Libby P, Kurt-Jones EA (2000) Cutting edge: heat shock protein (HSP) 60 activates the innate immune response: CD14 is an essential receptor for HSP60 activation of mononuclear cells. J Immunol 164:13-17

Laemmli UK (1970) Cleavage of structural proteins during the assembly of the head of bacteriophage T4. Nature 227: 680-685

LaFrentz BR, LaPatra SE, Jones GR, Congleton JL, Sun B, Cain KD (2002) Characterization of serum and mucosal antibody responses and relative percent survival in rainbow trout, Oncorhynchus mykiss (Walbaum), following immunization and challenge with Flavobacterium psychrophilum. J Fish Dis 25:703-713
LaFrentz BR, LaPatra SE, Jones GR, Cain KD (2003) Passive immunization of rainbow trout, Oncorhynchus mykiss (Walbaum), against Flavobacterium psychrophilum, the causative agent of bacterial coldwater disease and rainbow trout fry syndrome. J Fish Dis 26:377-384

LaFrentz BR, LaPatra SE, Jones GR, Cain KD (2004) Protective immunity in rainbow trout Oncorhynchus mykiss following immunization with distinct molecular mass fractions isolated from Flavobacterium psychrophilum. Dis Aquat Org 59:17-26

Langen H, Takács B, Evers S, Berndt P, Lahm HW, Wipf B, Gray C, Fountoulakis M (2000) Two-dimensional map of the proteome of Haemophilus influenzae. Electrophoresis 21:411-429

Lee BY, Horwitz MA (1995) Identification of macrophage and stress-induced proteins of Mycobacterium tuberculosis. J Clin Investig 96:245-249

Lehmann J, Mock D, Stürenberg FJ, Bernardet JF (1991) First isolation of Cytophaga psychrophila from a systemic disease in eel and cyprinids. Dis Aquat Org 10:217-220

Madetoja J, Lönnström LG, Björkblom C, Uluköy G and 5 others (2006) Efficacy of injection vaccines against Flavobacterium psychrophilum in rainbow trout, Oncorhynchus mykiss (Walbaum). J Fish Dis 29:9-20

Madsen L, Dalsgaard I (2000) Comparative studies of Flavobacterium psychrophilum isolates: ribotypes, plasmid profiles, serotypes and virulence. J Fish Dis 23: 211-218

Massias B, Dumetz F, Urdaci MC, Le Hénaff M (2004) Identification of P18, a surface protein produced by the fish pathogen Flavobacterium psychrophilum. J Appl Microbiol 97:574-580

Merle C, Faure D, Urdaci MC, Le Hénaff M (2003) Purification and characterization of a membrane glycoprotein from the fish pathogen Flavobacterium psychrophilum. J Appl Microbiol 94:1120-1127

Michel C, Kerouault B, Martin C (2003) Chloramphenicol and florfenicol susceptibility of fish-pathogenic bacteria isolated in France: comparison of minimum inhibitory concentration, using recommended provisory standards for fish bacteria. J Appl Microbiol 95:1008-1015

Nilsson CL, Larsson T, Gustafsson E, Karlsson KA, Davidsson P (2000) Identification of protein vaccine candidates from Helicobacter pylori using a preparative two-dimensional electrophoretic procedure and mass spectrometry. Anal Chem 72:2148-2153

Noll A, Roggenkamp A, Heesemann J, Autenrieth IB (1994) Protective role for heat shock protein-reactive alpha beta $\mathrm{T}$ cells in murine yersiniosis. Infect Immun 62:2784-2791

Obach A, Laurencin FB (1991) Vaccination of rainbow trout Oncorhynchus mykiss against the visceral form of coldwater disease. Dis Aquat Org 12:13-15

Qoronfleh MW, Bortner CA, Schwartzberg P, Wilkinson BJ (1998) Enhanced levels of Staphylococcus aureus stress protein GroEL and DnaK homologs early in infection of human epithelial cells. Infect Immun 66:3024-3027

Rahman MH, Kuroda A, Dijkstra JM, Kiryu I, Nakanishi T, Ototake M (2002) The outer membrane fraction of Flavobacterium psychrophilum induces protective immunity in rainbow trout and ayu. Fish Shellfish Immunol 12: 169-179

Rico AI, Gironès, NR, Fresno $M$, Alonso $C$, Requena JM (2002) The heat shock proteins, Hsp70 and Hsp83, of Leishmania infantum are mitogens for mouse B cells. Cell Stress Chaperones 7:339-346

Rowley A, Choudhary JS, Marzioch M, Ward MA, Weir M, Solari RC, Blackstock WP (2000) Applications of protein 
mass spectrometry in cell biology. Methods 20:383-397

Rucker RR, Earp BJ, Ordal EJ (1953) Infectious diseases of Pacific salmon. Trans Am Fish Soc 83:297-312

Scorpio A, Johnson P, Laquerre A, Nelson DR (1994) Subcellular localization and chaperone activities of Borrelia burgdorferi Hsp60 and Hsp70. J Bacteriol 176:6449-6456

Secades P, Alvarez B, Guijarro JA (2001) Purification and characterization of a psychrophilic, calcium-induced, growth-phase-dependent metalloprotease from the fish pathogen Flavobacterium psychrophilum. Appl Environ Microbiol 67:2436-2444

Secades P, Alvarez B, Guijarro JA (2003) Purification and properties of a new psychrophilic metalloprotease (Fpp2) in the fish pathogen Flavobacterium psychrophilum. FEMS Microbiol Lett 226:273-279

Shevchenko A, Wilm M, Vorm O, Mann M (1996) Mass spectrometric sequencing of proteins from silver-stained polyacrylamide gels. Anal Chem 68:850-858

Srinivasa Rao PS, Yamada Y, Tan YP, Leung KY (2004) Use of proteomics to identify novel virulence determinants that are required for Edwardsiella tarda pathogenesis. Mol Microbiol 53:573-586

Srivastava PK, Menoret A, Basu S, Binder RJ, McQuade KL (1998) Heat shock proteins come of age: primitive functions acquire new roles in an adaptive world. Immunity 8: $657-665$

Sudheesh PS, Xu HS (2001) Pathogenicity of Vibrio para-

Editorial responsibility: Stewart Johnson,

Halifax, Nova Scotia, Canada haemolyticus in tiger prawn Penaeus monodon Fabricius: possible role of extracellular proteases. Aquaculture 196: $37-46$

Suzue K, Young RA (1996) Adjuvant-free hsp70 fusion protein system elicits humoral and cellular immune responses to HIV-1 p24. J Immunol 156:873-879

Tan YP, Lin Q, Wang XH, Joshi S, Hew CL, Leung KY (2002) Comparative proteomic analysis of extracellular proteins of Edwardsiella tarda. Infect Immun 70:6475-6480

Vytvytska O, Nagy E, Bluggel M, Meyer HE, Kurzbauer R, Huber LA, Klade CS (2002) Identification of vaccine candidate antigens of Staphylococcus aureus by serological proteome analysis. Proteomics 2:580-590

Wakabayashi H, Toyama T, Iida T (1994) A study on serotyping of Cytophaga psychrophila isolated from fishes in Japan. Fish Pathol 29:101-104

Wang Y, Kelly CG, Karttunen JT, Whittall T and 9 others (2001) CD40 is a cellular receptor mediating mycobacterial heat shock protein 70 stimulation of CC-chemokines. Immunity 15:971-983

Wilhelm V, Soza C, Martínez R, Rosemblatt M, Burzio LO, Valenzuela PDT (2005) Production and immune response of recombinant Hsp60 and Hsp70 from the salmon pathogen Piscirickettsia salmonis. Biol Res 38:69-82

Zügel U, Kaufmann SH (1999) Role of heat shock proteins in protection from and pathogenesis of infectious diseases. Clin Microbiol Rev 12:19-39

Submitted: January 26, 2006; Accepted: October 31, 2006 Proofs received from author(s): January 31, 2007 